\title{
LEAF CONTENTS AND BIOCHEMICAL CYCING OF NUTRIENTS IN ACCESSIONS OF UMBU AND UMBU-CAJA ${ }^{1}$
}

\author{
LUANA JÉSSICA SOUZA SANTOS ${ }^{2}$, ALESSANDRO DE MAGALHÃES ARANTES ${ }^{2}$, SÉRGIO LUIZ RODRIGUES \\ DONATO $^{2}$, CLEITON FERNANDO BARBOSA BRITO ${ }^{*}$, MARIA AUXILIADORA COÊLHO DE LIMA ${ }^{4}$, VAGNER \\ ALVES RODRIGUES FILHO 5
}

\begin{abstract}
Information is needed on the characteristics of potential accessions of Spondias tuberosa Arruda Câmara (umbu) and Spondias sp.(umbu-caja) for commercial planting and preservation. Thus, the objective was to evaluate the leaf contents and cycling of nutrients of 15 accessions of umbu and one of umbucaja. The treatments consisted of 16 accessions: BGU-44, BGU-45, BGU-47, BGU-48, BGU-50, BGU-75, EPAMIG-01, EPAMIG-03, EPAMIG-04, EPAMIG-05, EPAMIG-06, EPAMIG-07, EPAMIG-09, EPAMIG13, umbu of unknown origin and the umbu-caja Princesa. A completely randomized experimental design was adopted, with three replicates, consisting of one plant each. Nutrient contents in the leaves were measured in the leaf flushing and leaf senescence phases in the 2015/2016 and 2016/2017 seasons, and the N, P, K and Mg retranslocation rates were determined. The accessions showed average leaf nutrient contents of 28.6, 27.6, 9.5, 4.20, 2.5 and $2.0 \mathrm{~g} \mathrm{~kg}^{-1}$ with the descending order $\mathrm{N}>\mathrm{Ca}>\mathrm{K}>\mathrm{Mg}>\mathrm{S}>\mathrm{P}$, respectively, and 103.61, 86.22, 82.12, $60.2,16.0$ and $3.52 \mathrm{mg} \mathrm{kg}^{-1}$ of $\mathrm{Fe}>\mathrm{B}>\mathrm{Na}>\mathrm{Mn}>\mathrm{Zn}>\mathrm{Cu}$, respectively. The accession BGU-48 had higher $\mathrm{N}$ and $\mathrm{P}$ retranslocation efficiency in the leaves and BGU-50 showed recycling efficiency for $\mathrm{K}$ and $\mathrm{Mg}$. The order of retranslocation rates is $\mathrm{K}>\mathrm{P}>\mathrm{N}>\mathrm{Mg}$, being higher in the $2015 / 2016$ season.
\end{abstract}

Keywords: Spondias spp.. Genetic resources. Variability. Nutrients.

\section{TEOR FOLIAR E CICLAGEM BIOQUÍMICA DE NUTRIENTES EM ACESSOS DE UMBUZEIRO E UMBU-CAJAZEIRA}

RESUMO - O umbuzeiro e umbu-cajazeira demandam informações sobre as características de acessos potenciais para implantação comercial e preservação. Assim, objetivou-se avaliar o teor foliar e ciclagem dos nutrientes de 15 acessos de umbuzeiro e um de umbucajazeira. Os tratamentos constaram de 16 acessos: BGU44, BGU-45, BGU-47, BGU-48, BGU-50, BGU-75, EPAMIG-01, EPAMIG-03, EPAMIG-04, EPAMIG-05, EPAMIG-06, EPAMIG-07, EPAMIG-09, EPAMIG-13, umbuzeiro de origem desconhecida e umbu-cajazeira Princesa. Adotou-se o delineamento experimental inteiramente casualizado, com três repetições, constituídas de uma planta cada. Foram mensurados os teores de nutrientes nas folhas, nas fases de emissão de fluxo foliar e senescência das folhas, nas safras de 2015/2016 e 2016/2017, e determinou-se a taxa de retranslocação de N, P, $\mathrm{K}$ e Mg. Verificou-se que os acessos denotaram teores médios de nutrientes na folha de 28,$6 ; 27,6 ; 9,5 ; 4,20$; 2,5 e $2,0 \mathrm{~g} \mathrm{~kg}^{-1}$ com ordem decrescente $\mathrm{N}>\mathrm{Ca}>\mathrm{K}>\mathrm{Mg}>\mathrm{S}>\mathrm{P}$, respectivamente, e 103,61; 86,22; 82,12; 60,2; 16,0 e 3,52 $\mathrm{mg} \mathrm{kg}^{-1}$ de $\mathrm{Fe}>\mathrm{B}>\mathrm{Na}>\mathrm{Mn}>\mathrm{Zn}>\mathrm{Cu}$, respectivamente. $\mathrm{O}$ acesso BGU-48 revelou maior eficiência de retranslocação de N e P nas folhas e o BGU-50 expressou eficiência de reciclagem para $\mathrm{K}$ e $\mathrm{Mg}$. A ordem das taxas de retranslocação é $\mathrm{K}>\mathrm{P}>\mathrm{N}>\mathrm{Mg}$ sendo maior na safra 2015/2016.

Palavras-Chave: Spondias spp.. Recursos genéticos. Variabilidade. Nutrientes.

\footnotetext{
* Corresponding author

${ }^{1}$ Received for publication in $12 / 16 / 2019$; accepted in $05 / 13 / 2020$.

Paper extracted from the master dissertation of the first author.

${ }^{2}$ Agriculture Sector, Instituto Federal de Educação, Ciência e Tecnologia Baiano, Guanambi, BA, Brazil; llaannaa2@gmail.com - ORCID: 0000-0003-4084-1245, alessando.arantes@ifbaiano.edu.br - ORCID: 0000-0002-7520-9891, sergio.donato@ifbaiano.edu.br - ORCID: 0000-0002-7719-4662.

${ }^{3}$ Department of Agricultural Sciences, Universidade Estadual de Montes Claros, Janaúba, MG, Brazil; cleiton.ibce@hotmail.com - ORCID: 0000-0001-9423-4980.

${ }^{4}$ Agricultural Research Center Semi-arid Tropical, Embrapa Semiárido, Petrolina, PE, Brazil; auxiliadora.lima@embrapa.br - ORCID: 0000 $-0002-2000-1655$.

${ }^{5}$ Department of Microbiology, Universidade Federal de Viçosa, Viçosa, MG, Brazil; vagner.rodrigues@ufv.br - ORCID:0000-0001-77027445 .
}

Rev. Caatinga, Mossoró, v. 33, n. 3, p. 690 - 701, jul. - set., 2020 


\section{INTRODUCTION}

Spondias tuberosa Arruda Câmara (Umbu) and Spondias sp. (umbu-caja) are fruit plants of the Anacardiaceae family, native to Northeastern Brazil (MERTENS et al., 2017), with mechanisms of survival to the water scarcity and irregular rainfall distribution that prevail in the Brazilian semi-arid region, such as leaf abscission, roots with structures called tubers or xylopodia, popularly known as 'umbu potatoes' with the function of storing water and nutrients (MITCHELL; DALY, 2015), in addition to efficient control of leaf transpiration (LIMA FILHO; AIDAR, 2016).

Due to the characteristics of adaptation to the edaphoclimatic conditions of the semi-arid region, these species have environmental and socioeconomic importance for the region, because their fruits are commercialized in an extractive way, with great expansion capacity for commercial plantations destined for the markets of fresh products and products processed from pulp and peel. Fruit collection is directly affected, in order of importance, by flavor, size, and quantity of fruit pulp (LINS NETO; PERONI; ALBUQUERQUE, 2010).

In this context, despite the advances of research in the field of fruit characterization (BASTOS; MARTINEZ; SOUZA, 2016; CAMPOS et al., 2018), definition of suitable rootstocks (LIMA FILHO; SANTOS, 2009), seedling production by cuttings (MENDES et al., 2019) and physiological characterization (ANTUNES et al., 2016), umbu and umbu-caja currently have no recommended accessions for use on a productive scale or for a specific destination market, either for fresh consumption or for agroindustry, so studies need to be conducted (FREITAS et al., 2015).

Thus, the creation of Germplasm Banks and Collections are an important source of information in this selection process because, besides the preservation of species variability, reducing the effects of genetic erosion under natural conditions, they enable the characterization and documentation of different accessions for use in breeding programs or identification of insertion in a potential market (OLIVEIRA et al., 2016).

Studies with the different accessions in Germplasm Banks and Collections are still incipient and are necessary, mainly the nutritional evaluation in leaves of umbu and umbu-caja under field conditions, because the studies with nutritional characterization were carried out in the initial phase of seedling production with native umbu (GONÇALVES; NEVES; CARVALHO, 2006; SILVA; GONÇALVES; PINHO, 2005) or umbu in Caatinga forest system (ALBUQUERQUE et al., 2018).

Leaf contents are important to indicate the deficiency in quantity or absorption of nutrients in the plant. However, the nutrient absorption process is regulated by genetic control, in which selectivity and speed of absorption depend on genotype characteristics (FAQUIN, 2005). Thus, in addition to the supply of nutrients in the soil, the genetic characteristics of each accession can interfere in the leaf contents of nutrients. In this context, the objective was to evaluate the leaf contents and cycling of nutrients of 15 accessions of umbu and one of umbu-caja.

\section{MATERIAL AND METHODS}

The plants used in this study make up the Collection of Umbu and Umbu-caja Accessions of the Federal Institute of Education, Science and Technology of Bahia, Guanambi Campus, located in the municipality of Guanambi, BA, Ceraíma District, with the coordinates of $14^{\circ} 17^{\prime} 38.50^{\prime \prime} \mathrm{S}$ and $42^{\circ}$ $41^{\prime} 35.94 " \mathrm{~W}$ and altitude of $545 \mathrm{~m}$.

The umbu accessions used come from the municipalities of Lontra-MG (EPAMIG-01), Porteirinha-MG (EPAMIG-03 and EPAMIG-05), Janaúba-MG (EPAMIG-04), Mamonas-MG (EPAMIG-06) and Januária-MG (EPAMIG-07, EPAMIG-09 and EPAMIG-13), produced and provided by the EPAMIG North Collection in Nova Porteirinha, MG. Accessions from Anagé-BA (BGU44), Brumado-BA (BGU-45), São Gabriel-BA (BGU -47), América Dourada-BA (BGU-48), Santana-BA (BGU-50) and Macaúbas-BA (BGU-75) come from the Active Germplasm Bank of Umbu of Embrapa Semiarid, Petrolina, PE, and were provided by Embrapa Cassava and Tropical Fruits, Cruz das Almas, BA.

The umbu accession called unknown refers to a plant with no identification of origin, but considered of sweet fruit, provided by Embrapa Cassava and Tropical Fruits, Cruz das Almas, BA. The umbu-caja Princesa from Iaçú-BA was produced and provided by Embrapa Cassava and Tropical Fruits, Cruz das Almas, BA. The accession EPAMIG -01 (SATURNINO; GONÇALVES; SILVA, 2000) used in the study was provided by the EPAMIG North Accession Collection in Nova Porteirinha, MG. This accession comes from the municipality of Lontra, MG, Gangorra Community, at coordinates $15^{\circ} 48^{\prime} 27.23^{\prime \prime S} \quad$ Latitude and $44^{\circ} 18^{\prime} 27.21^{\prime \prime} \mathrm{W}$ Longitude, at altitude of $692 \mathrm{~m}$, and corresponds to the same accession BGU-68 identified by Santos, Nascimento and Oliveira (1999), registered in the Umbu Germplasm Bank of EMBRAPA. The fruits have a high value of fruit mass and are popularly called 'umbu Gigante' (giant umbu, in Portuguese), as well as the accession BGU-75, from the municipality of Macaúbas, BA.

The planting of grafted seedlings, provided by Embrapa Cassava and Tropical Fruits and the Agricultural Research Company of Minas Gerais EPAMIG North, was carried out on October 5 and 
December 5, 2007, respectively, at the quincunx spacing of $8 \times 8 \times 8 \mathrm{~m}$. The seedlings were planted in soil classified as Latossolo Vermelho-Amarelo (Oxisol), with typic, weak A horizon and medium texture, and the chemical characterization for each accession is described in Table 1. The pits were opened with diameter of $50 \mathrm{~cm}$ and depth of $60 \mathrm{~cm}$, using a soil auger. Basal fertilization was carried out with $500 \mathrm{~g}$ of single superphosphate, which supplies $90 \mathrm{~g}$ of $\mathrm{P}_{2} \mathrm{O}_{5}$, and $20 \mathrm{~L}$ of bovine manure. Topdressing fertilization, weed control, pruning to open the crown, removal of unwanted plants around the stem were performed according to Donato et al. (2019b).

Table 1. Chemical attributes of the soil for the evaluated accessions.

\begin{tabular}{|c|c|c|c|c|c|c|c|c|c|c|c|c|c|c|c|c|}
\hline 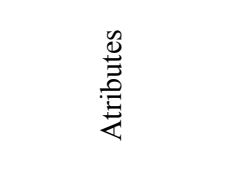 & 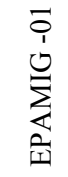 & 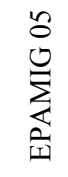 & 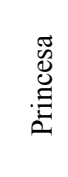 & $\stackrel{n}{\mathfrak{b}}$ & 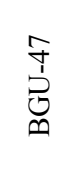 & 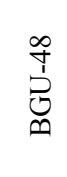 & 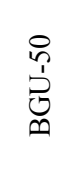 & 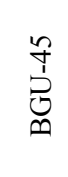 & 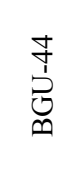 & 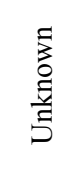 & 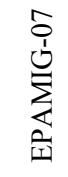 & 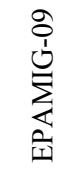 & 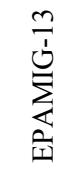 & 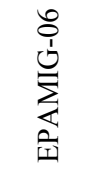 & 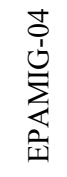 & 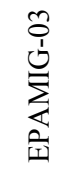 \\
\hline $\mathrm{pH}$ & 7.2 & 7.3 & 7.3 & 7.1 & 7.2 & 7.0 & 7.3 & 7.3 & 7.1 & 6.8 & 7.2 & 7.0 & 7.5 & 7.7 & 7.4 & 7.3 \\
\hline SOM (dag kg $\left.{ }^{-1}\right)$ & 1.7 & 1.3 & 1.2 & 1.1 & 1.7 & 1.2 & 1.2 & 1.3 & 1.4 & 1.3 & 1.8 & 1.2 & 1.7 & 2.5 & 1.8 & 1.5 \\
\hline$P\left(\mathrm{mg} \mathrm{dm}^{-3}\right)$ & 42.2 & 35.6 & 43.4 & 41.8 & 50.5 & 68.8 & 67.8 & 75.4 & 80.7 & 36.0 & 34.8 & 51.9 & 94.5 & 120.7 & 69.8 & 28.4 \\
\hline $\mathrm{K}^{+}\left(\mathrm{mg} \mathrm{dm}^{-3}\right)$ & 196 & 207 & 200 & 200 & 291 & 198 & 226 & 268 & 222 & 194 & 177 & 199 & 255 & 269 & 218 & 198 \\
\hline $\mathrm{Ca}^{2+}\left(\mathrm{cmol}_{\mathrm{c}} \mathrm{dm}^{-3}\right)$ & 3.4 & 3.3 & 3.3 & 3.4 & 3.6 & 2.9 & 3.3 & 3.2 & 2.8 & 2.9 & 3.2 & 2.9 & 3.9 & 3.8 & 3.3 & 3.7 \\
\hline $\mathrm{Mg}^{2+}\left(\mathrm{cmol}_{\mathrm{c}} \mathrm{dm}^{-3}\right)$ & 1.1 & 1.0 & 0.9 & 1.2 & 1.2 & 1.0 & 1.1 & 1.1 & 1.1 & 0.9 & 0.9 & 0.9 & 1.1 & 1.1 & 1.1 & 1.0 \\
\hline $\mathrm{Al}^{3+}\left(\mathrm{cmol}_{\mathrm{c}} \mathrm{dm}^{-3}\right)$ & 0.0 & 0.0 & 0.0 & 0.0 & 0.0 & 0.0 & 0.0 & 0.0 & 0.0 & 0.0 & 0.0 & 0.0 & 0.0 & 0.0 & 0.0 & 0.0 \\
\hline $\mathrm{H}+\mathrm{Al}\left(\mathrm{cmol}_{\mathrm{c}} \mathrm{dm}^{-3}\right)$ & 1.2 & 1.0 & 1.0 & 1.1 & 1.0 & 1.1 & 1.1 & 1.2 & 1.0 & 1.5 & 1.1 & 1.0 & 1.0 & 1.0 & 1.0 & 1.1 \\
\hline $\mathrm{SB}\left(\mathrm{cmol}_{\mathrm{c}} \mathrm{dm}^{-3}\right)$ & 5.0 & 5.0 & 4.9 & 5.1 & 5.6 & 4.6 & 5.1 & 5.1 & 4.6 & 4.4 & 4.6 & 4.4 & 5.7 & 5.7 & 5.0 & 5.3 \\
\hline $\mathrm{t}\left(\mathrm{cmol}_{\mathrm{c}} \mathrm{dm}^{-3}\right)$ & 5.0 & 5.0 & 4.9 & 5.1 & 5.6 & 4.6 & 5.1 & 5.1 & 4.6 & 4.4 & 4.6 & 4.4 & 5.7 & 5.7 & 5.0 & 5.3 \\
\hline $\mathrm{T}\left(\mathrm{cmol}_{\mathrm{c}} \mathrm{dm}^{-3}\right)$ & 6.2 & 6.1 & 5.9 & 6.3 & 6.7 & 5.7 & 6.1 & 6.3 & 5.6 & 5.9 & 5.7 & 5.5 & 6.8 & 6.7 & 6.0 & 6.5 \\
\hline V $(\%)$ & 81.3 & 83.0 & 82.7 & 81.7 & 84.0 & 80.3 & 81.3 & 81.3 & 81.3 & 74.7 & 80.0 & 81.0 & 84.7 & 84.7 & 83.3 & 82.7 \\
\hline $\mathrm{B}^{3-}\left(\mathrm{mg} \mathrm{dm}^{-3}\right)$ & 0.4 & 0.4 & 0.4 & 0.7 & 0.4 & 0.4 & 0.5 & 0.5 & 0.4 & 0.4 & 0.3 & 0.5 & 0.5 & 0.4 & 0.3 & 0.3 \\
\hline $\mathrm{Cu}^{2+}\left(\mathrm{mg} \mathrm{dm}^{-3}\right)$ & 0.6 & 0.6 & 0.5 & 0.6 & 0.4 & 0.4 & 1.8 & 1.1 & 0.6 & 0.4 & 0.4 & 0.5 & 0.7 & 1.6 & 0.6 & 0.3 \\
\hline $\mathrm{Fe}^{2+}\left(\mathrm{mg} \mathrm{dm}^{-3}\right)$ & 23.4 & 16.7 & 16.6 & 45.0 & 19.4 & 22.6 & 34.0 & 39.8 & 49.6 & 21.1 & 23.4 & 29.4 & 39.4 & 53.6 & 21.7 & 24.9 \\
\hline $\mathrm{Mn}^{2+}\left(\mathrm{mg} \mathrm{dm}{ }^{-3}\right)$ & 70.2 & 77.8 & 75.2 & 58.9 & 86.8 & 67.6 & 57.1 & 64.9 & 78.4 & 85.9 & 92.8 & 72.4 & 80.1 & 87.0 & 87.5 & 95.1 \\
\hline $\left.\mathrm{Zn}^{2+}(\mathrm{mg} \mathrm{dm})^{-3}\right)$ & 3.2 & 3.1 & 2.7 & 2.9 & 3.6 & 4.2 & 7.1 & 3.9 & 4.3 & 4.3 & 5.4 & 4.1 & 3.2 & - & - & - \\
\hline$P_{\text {rem }}\left(\mathrm{mg} \mathrm{L}^{-1}\right)$ & 40.5 & 41.3 & 41.9 & 41.8 & 41.7 & 42.1 & 42.7 & 42.5 & 41.9 & 38.9 & 41.0 & 42.4 & 43.9 & 42.7 & 41.8 & 38.1 \\
\hline $\left.\mathrm{EC}(\mathrm{dS} \mathrm{m})^{-1}\right)$ & 0.7 & 1.0 & 1.4 & 1.4 & 1.6 & 1.4 & 0.8 & 0.8 & 1.1 & 1.0 & 0.7 & 1.0 & 0.8 & 0.9 & 0.9 & 0.8 \\
\hline
\end{tabular}

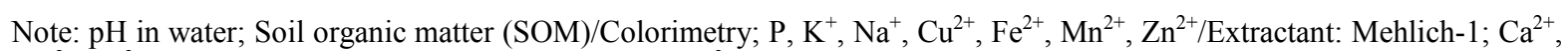

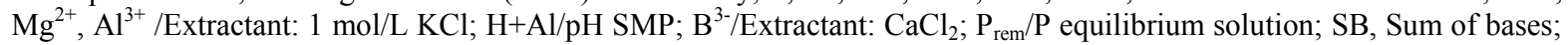
$\mathrm{t}$, effective $\mathrm{CEC}$; T, CEC at $\mathrm{pH} \mathrm{7;} \mathrm{V,} \mathrm{Base} \mathrm{saturation;} \mathrm{m,} \mathrm{Aluminum} \mathrm{saturation;} \mathrm{P-rem,} \mathrm{Remaining} \mathrm{phosphorus;} \mathrm{EC,}$ Electrical conductivity.

The first top-dressing fertilization, in February 2008, consisted of the application of $100 \mathrm{~g}$ of ammonia sulfate, which provides $20 \mathrm{~g}$ of $\mathrm{N}$, and $20 \mathrm{~L}$ of bovine manure per plant. In November 2008, the second top-dressing fertilization was carried out with $500 \mathrm{~g}$ of $04-14-08$ (NPK) and $36 \mathrm{~L}$ of bovine manure per plant. The third top-dressing fertilization occurred in March 2009, with $100 \mathrm{~g}$ of urea, $50 \mathrm{~g}$ of potassium chloride and $36 \mathrm{~L}$ of bovine manure. At the beginning of the rainy season, in October 2009, the area was fertilized with one bag of bovine manure, $300 \mathrm{~g}$ of MAP and $50 \mathrm{~g}$ of urea per plant. In March 2010, the plants were fertilized with $200 \mathrm{~g}$ of 14-07-28 (NPK) and $100 \mathrm{~g}$ of urea for each tree. In the rainy season of October 2010, plants were fertilized with $300 \mathrm{~g}$ of MAP, $70 \mathrm{~g}$ of urea, $70 \mathrm{~g}$ of potassium chloride and $36 \mathrm{~L}$ of bovine manure per plant. Subsequently, in March 2011, fertilization was carried out with $36 \mathrm{~L}$ of sheep manure per plant. In December 2011, $800 \mathrm{~g}$ of single superphosphate, 50 $\mathrm{g}$ of urea, $100 \mathrm{~g}$ of potassium chloride and $36 \mathrm{~L}$ of bovine manure were applied per plant. In January 2013, fertilization was performed with $1 \mathrm{~kg}$ of single superphosphate, $150 \mathrm{~g}$ of potassium chloride, $100 \mathrm{~g}$ of urea and $72 \mathrm{~L}$ of bovine manure per plant. In March 2014, the trees were fertilized with $200 \mathrm{~g}$ of MAP, $100 \mathrm{~g}$ of potassium chloride and $60 \mathrm{~L}$ of bovine manure mixed with grass. In May 2015, 36 L of bovine manure were applied per plant. After this period, a new fertilization was carried out with $500 \mathrm{~g}$ of 04-30-10 (NPK) and $36 \mathrm{~L}$ of bovine manure for each plant only in February 2017.

The values of maximum and minimum temperatures, relative humidity, rainfall and evapotranspiration along the experimental periods are shown in Figure 1. Rainfall occurred in the months of November/2015 to February/2016 (597.76 $\mathrm{mm})$, supporting the flowering of the 2015/2016 season, and from November 2016 to May 2017 $(294.40 \mathrm{~mm})$, which influenced fruit growth in the 2016/2017 season.

Rev. Caatinga, Mossoró, v. 33, n. 3, p. 690 - 701, jul. - set., 2020 


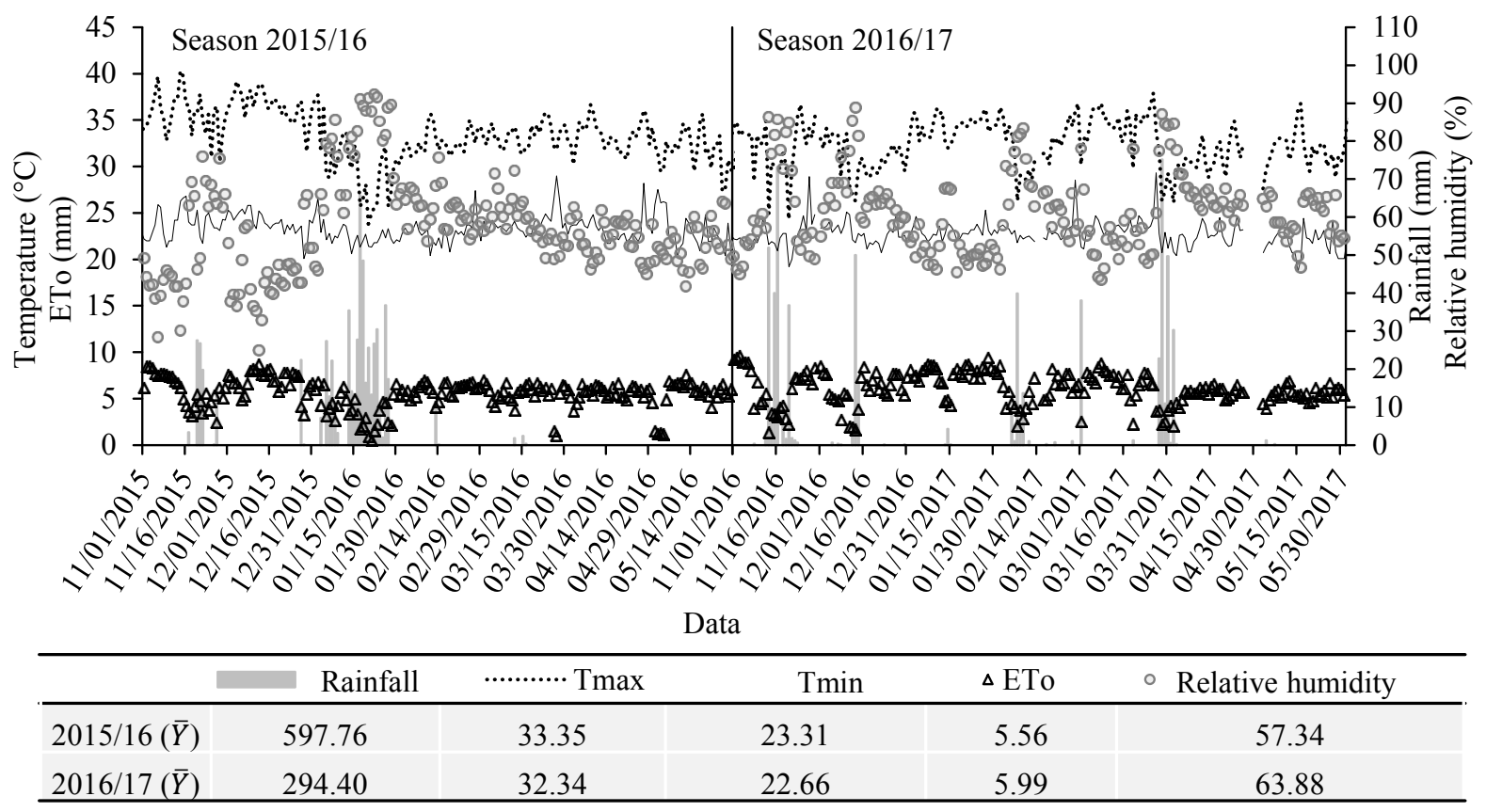

Source: Meteorological data: Federal Institute of Education, Science and Technology of Bahia - Automatic Meteorological Station - Guanambi Campus.

Figure 1. Maximum temperature (Tmax), minimum temperature (Tmin), relative humidity, rainfall and evapotranspiration (ETo) with respective mean values referring to the 2015/16 and 2016/17 seasons.

The treatments consisted of 15 umbu accessions (BGU-44, BGU-45, BGU-47, BGU-48, BGU-50, BGU-75, EPAMIG-01, EPAMIG-03, EPAMIG-04, EPAMIG-05, EPAMIG-06, EPAMIG07, EPAMIG-09, EPAMIG-13, umbu of unknown origin) and one umbu-caja accession (Princesa). A completely randomized experimental design with three replicates was used, consisting of one plant each. The arrangement was in split-plot-in-time: $16 \mathrm{x}$ $2 \times 2$ for nutrient contents in leaves (accessions $\mathrm{x}$ cycle $\mathrm{x}$ phase).

The evaluations were carried out in the 2015/16 and 2016/17 seasons, i.e., in plants at eight and nine years after planting. Sampling consisted in collecting leaves, without petiole, in four quadrants of the crown. Twenty units of the second or third leaflet of the developed leaf were collected from each plant. The collection period occurred at two distinct phenological stages: phase I, period of complete formation of the crown (leaf flushing), occurred on December 18, 2015 (cycle I) and December 22, 2016 (cycle II); and phase II, period of color change of leaves from green to yellow and fall of leaves or senescence, sampled on April 14, 2016 (cycle I) and March 21, 2017 (cycle II). Cycle I was considered the $2015 / 2016$ season and cycle II was considered the $2016 / 2017$ season.

After field collection, samples of umbu and umbu-caja leaves were dried in a ventilation oven at $60{ }^{\circ} \mathrm{C}$ (Temperature accuracy: $\pm 0.2{ }^{\circ} \mathrm{C}$ ) until they reached constant weight, and then sent to the Soil Laboratory of EPAMIG North, Nova Porteirinha, MG, and evaluated for the contents of the macronutrients nitrogen $(\mathrm{N})$, phosphorus $(\mathrm{P})$, potassium $(\mathrm{K})$, calcium $(\mathrm{Ca})$, magnesium $(\mathrm{Mg})$ and sulfur (S), expressed in $\mathrm{g} \mathrm{kg}^{-1}$, and boron (B), copper $(\mathrm{Cu})$, iron $(\mathrm{Fe})$, manganese $(\mathrm{Mn})$, zinc $(\mathrm{Zn})$ and sodium $(\mathrm{Na})$, expressed in $\mathrm{mg} \mathrm{kg}^{-1}$. The analytical determinations were performed according to Malavolta, Vitti and Oliveira (1989): N, sulfuric digestion with the Kjeldahl method; P, K, S, Ca, Mg, $\mathrm{Cu}, \mathrm{Fe}, \mathrm{Mn}, \mathrm{Zn}$ and $\mathrm{Na}$, nitric-perchloric digestion and $\mathrm{B}$, dry digestion.

The retranslocation rate or magnitude of biochemical cycling of nutrients in umbu and umbucaja leaves was estimated for the nutrients of high mobility in the plant, namely $\mathrm{N}, \mathrm{P}, \mathrm{K}$ and $\mathrm{Mg}$. Therefore, $\mathrm{Ca}$ was used as a marker and the rates were estimated using Equation 1, adapted by Chuyong, Newbery and Songwe (2000).

$$
\% \operatorname{ReNut}=1-\frac{\left[\frac{\text { Mobilenut.(senescent leaves) }}{\mathrm{Ca}(\text { senescent leaves }))}\right]}{\left[\frac{\text { Mobile nut.(young leaves) }}{\mathrm{Ca}(\text { young leaves })}\right]} \times 100
$$

Where:

$\%$ ReNut $=$ percentage of the retranslocated nutrient.

Mobile Nut. (senescent leaves)/Ca(senescent leaves $)=$ relationship between the contents of mobile nutrients and $\mathrm{Ca}$ content in senescent leaves;

Mobile Nut. (young leaves)/Ca(young leaves) $=$ relationship between the contents of mobile nutrients and $\mathrm{Ca}$ content in young leaves. 
The data of leaf contents of nutrients were subjected to analysis of variance, and the means of the cycle and phase factors were compared by $\mathrm{F}$ test $(\mathrm{P} \leq 0.05)$, while those referring to the accessions and significant interactions were grouped by the ScottKnott criterion $(\mathrm{P} \leq 0.05)$.

\section{RESULTS AND DISCUSSION}

The contents of $\mathrm{N}, \mathrm{P}, \mathrm{S}$ and $\mathrm{Ca}$ in the leaves of umbu and umbu-caja were affected by the interaction between the factors accessions, cycles and evaluation phases. The $\mathrm{K}$ and $\mathrm{Mg}$ contents were affected by the interactions between accessions and cycles and between accessions and phases (Table 2). The leaf contents of $\mathrm{N}$ in the cycles varied between accessions, with formation of two groups by the Scott-Knott criterion. In the 2015/16 cycle, the accessions EPAMIG-01, EPAMIG-04, EPAMIG-06, EPAMIG-09, EPAMIG-13, BGU-44, BGU-48 and BGU-50 showed higher $\mathrm{N}$ content in leaf flushing. The accessions 06, EPAMIG-09, EPAMIG-13, BGU $-44, \mathrm{BGU}-48$ and BGU-50 had higher $\mathrm{N}$ content in the leaf flushing of the 2016/17 cycle.

Nitrogen contents for the accessions EPAMIG-07 and umbu of unknown origin as well as boron contents for EPAMIG-01, BGU-48, BGU-50, EPAMIG-07, EPAMIG-09, EPAMIG-06, Princesa umbu-caja and umbu of unknown origin were not determined because the number of 20 sampled units was not sufficient to perform leaf analysis. The number of leaflet units was pre-established in this study since there is no reference for sampling aimed at complete nutrient analysis in umbu and umbucaja.

In general, higher leaf $\mathrm{N}$ contents were observed in the leaf flushing phase of the 2015/2016 season. The accessions BGU-45 and Princesa umbucaja in the 2015/2016 cycle and the accessions EPAMIG-01, EPAMIG-06 and Princesa umbu-caja in the 2016/2017 cycle maintained constant leaf $\mathrm{N}$ contents between leaf flushing and senescence, while the other accessions reduced their $\mathrm{N}$ contents in the senescent phase. The accessions, evaluated in two production cycles and in two evaluation phases, had average $\mathrm{N}$ contents of $28.6 \mathrm{~g} \mathrm{~kg}^{-1}$, consistent with the chemical composition of leaves of adult umbu plants, which have an average $\mathrm{N}$ content of $29.0 \mathrm{~g} \mathrm{~kg}^{-1}$ (MEDEIROS; SANTOS; TERTULIANO, 2008), and with another species of Spondias (ISAH; OMOROGIUWA; OKUNADE, 2013).

The leaf contents of $\mathrm{P}$ differed between accessions, only in the leaf flushing phase of the
2015/2016 season, forming four groups. In addition, the highest $\mathrm{P}$ contents were observed, in general, in the leaf flushing phase of the $2015 / 2016$ season. The accessions showed a reduction in $\mathrm{P}$ contents in the senescent leaves of the two evaluated seasons, except for EPAMIG-01, EPAMIG-05, BGU-44, BGU-47, BGU-48 and Princesa umbu-caja, in the $2016 / 2017$ season. The average P content among the accessions, for the two production cycles and the two evaluation phases, was $2.0 \mathrm{~g} \mathrm{~kg}^{-1}$.

Leaf contents of $\mathrm{S}$ varied between accessions in the leaf flushing phase of the 2015/16 season, with three groups being formed. In general, the accessions had higher $\mathrm{S}$ contents in the leaf flushing phase compared to the senescence, verified in the $2015 / 2016$ season. In the $2016 / 17$ season, the S contents varied in two groups between accessions in the senescence phase. The contents remained constant between leaf flushing and senescence, except for the accessions BGU-47 and EPAMIG-09, which reduced their $\mathrm{S}$ contents in the senescence, in the 2016/17 cycle. The accessions were characterized by average $\mathrm{S}$ content of $2.5 \mathrm{~g} \mathrm{~kg}^{-1}$, in the two production cycles and in the two evaluation phases. These contents were close to those reported by Medeiros, Santos and Tertuliano (2008), who observed $2.4 \mathrm{~g} \mathrm{~kg}^{-1}$ in leaves of adult umbu tree.

$\mathrm{S}$ participates in the structure of proteins, being necessary to reduce sulfate (VITTI et al., 2018). According to the authors, during leaf expansion, the evolution of sulfate reduction is maximum, but decreases dramatically after leaf maturity, which could be one of the justifications for the reduction in the $\mathrm{S}$ contents of senescent leaves in the 2015/2016 season. The constant S content in the phases of leaf flushing and senescence in the $2016 / 2017$ season can be explained by the low mobility of this nutrient in the plant, which reduces the influence of the sink on its translocation. Considering that sulfate is transported mainly in the root-leaf direction, the plant has little capacity to translocate sulfur via phloem in the leaf-root direction (MARSCHNER, 2012).

Another hypothesis for the higher contents of nutrients, including $\mathrm{S}$, in the leaf flushing phase of the 2015/2016 season, and subsequent reduction, would be climate interference. In 2015, the low levels of rainfall (Figure 1) led to lower nutrient storage in the xylopodia, due to lower root absorption. The following rains must have enabled more efficient absorption of the nutrients available in the soil, which resulted in an initial accumulation in young leaves and then dilution of the nutrient concentration, later observed in the senescent leaves. 
L. J. S. SANTOS et al.

Table 2. Leaf contents of nitrogen $(\mathrm{N})$, phosphorus $(\mathrm{P})$, sulfur $(\mathrm{S})$, calcium $(\mathrm{Ca})$, potassium $(\mathrm{K})$ and magnesium $(\mathrm{Mg})$ of fifteen accessions of umbu and one of umbu-caja in the phases of leaf flushing (phase I) and senescence (phase II) in two production cycles represented by the seasons of 2015/16 (cycle I) and 2016/17 (cycle II).

\begin{tabular}{|c|c|c|c|c|c|c|c|c|}
\hline \multirow{3}{*}{ Accessions } & \multicolumn{4}{|c|}{ 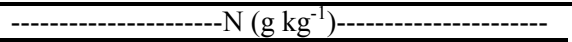 } & \multicolumn{4}{|c|}{ 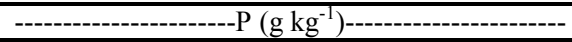 } \\
\hline & \multicolumn{2}{|c|}{ Clycle I } & \multicolumn{2}{|c|}{ Clycle II } & \multicolumn{2}{|c|}{ Clycle I } & \multicolumn{2}{|c|}{ Clycle II } \\
\hline & Phase I & Phase II & Phase I & Phase II & Phase I & Phase II & Phase I & Phase II \\
\hline EPAMIG-01 & $35.9 \mathrm{Aa}$ & $26.3 \mathrm{Bb}$ & $27.5 \mathrm{Ba}$ & $24.7 \mathrm{Aa}$ & $3.0 \mathrm{Ca}$ & $1.4 \mathrm{Ab}$ & $1.6 \mathrm{Aa}$ & $1.4 \mathrm{Aa}$ \\
\hline EPAMIG-05 & $30.9 \mathrm{Ba}$ & $27.2 \mathrm{Bb}$ & $26.5 \mathrm{Ba}$ & $23.7 \mathrm{Ab}$ & $2.4 \mathrm{Da}$ & $1.4 \mathrm{Ab}$ & $1.5 \mathrm{Aa}$ & $1.3 \mathrm{Aa}$ \\
\hline BGU-75 & $30.7 \mathrm{Ba}$ & $24.1 \mathrm{Bb}$ & $27.4 \mathrm{Ba}$ & $22.5 \mathrm{Bb}$ & $3.2 \mathrm{Ca}$ & $1.4 \mathrm{Ab}$ & $1.8 \mathrm{Aa}$ & $1.1 \mathrm{Ab}$ \\
\hline BGU-47 & $33.1 \mathrm{Ba}$ & $27.7 \mathrm{Bb}$ & $25.7 \mathrm{Ba}$ & $19.8 \mathrm{Bb}$ & $3.3 \mathrm{Ca}$ & $1.4 \mathrm{Ab}$ & $1.6 \mathrm{Aa}$ & $1.1 \mathrm{Aa}$ \\
\hline BGU-48 & $38.7 \mathrm{Aa}$ & $26.8 \mathrm{Bb}$ & $28.9 \mathrm{Aa}$ & $25.7 \mathrm{Ab}$ & $3.8 \mathrm{Ba}$ & $1.3 \mathrm{Ab}$ & $1.8 \mathrm{Aa}$ & $1.4 \mathrm{Aa}$ \\
\hline BGU-50 & $39.4 \mathrm{Aa}$ & $26.5 \mathrm{Bb}$ & $33.1 \mathrm{Aa}$ & $24.8 \mathrm{Ab}$ & 4.4 Aa & $1.5 \mathrm{Ab}$ & $1.8 \mathrm{Aa}$ & $1.2 \mathrm{Ab}$ \\
\hline BGU-45 & $33.1 \mathrm{Ba}$ & $33.1 \mathrm{Aa}$ & $26.9 \mathrm{Ba}$ & $19.9 \mathrm{Bb}$ & $3.1 \mathrm{Ca}$ & $1.3 \mathrm{Ab}$ & $1.6 \mathrm{Aa}$ & $1.0 \mathrm{Ab}$ \\
\hline BGU-44 & $39.1 \mathrm{Aa}$ & $26.7 \mathrm{Bb}$ & $30.6 \mathrm{Aa}$ & $26.4 \mathrm{Ab}$ & $4.1 \mathrm{Ba}$ & $1.5 \mathrm{Ab}$ & $1.8 \mathrm{Aa}$ & $1.2 \mathrm{Aa}$ \\
\hline EPAMIG-07 & - & - & - & - & $3.0 \mathrm{Ca}$ & $1.5 \mathrm{Ab}$ & $1.8 \mathrm{Aa}$ & $1.1 \mathrm{Ab}$ \\
\hline EPAMIG-09 & $35.1 \mathrm{Aa}$ & $28.1 \mathrm{Bb}$ & $32.6 \mathrm{Aa}$ & $23.6 \mathrm{Ab}$ & $4.5 \mathrm{Aa}$ & $1.6 \mathrm{Ab}$ & $2.1 \mathrm{Aa}$ & $1.3 \mathrm{Ab}$ \\
\hline EPAMIG-13 & $34.7 \mathrm{Aa}$ & $27.0 \mathrm{Bb}$ & $30.6 \mathrm{Aa}$ & $22.4 \mathrm{Bb}$ & $3.4 \mathrm{Ca}$ & $1.6 \mathrm{Ab}$ & $1.9 \mathrm{Aa}$ & $1.2 \mathrm{Ab}$ \\
\hline EPAMIG-06 & $36.4 \mathrm{Aa}$ & $25.9 \mathrm{Bb}$ & $29.7 \mathrm{Aa}$ & $27.3 \mathrm{Aa}$ & $3.9 \mathrm{Ba}$ & $1.4 \mathrm{Ab}$ & $2.0 \mathrm{Aa}$ & $1.3 \mathrm{Ab}$ \\
\hline EPAMIG-04 & $36.2 \mathrm{Aa}$ & $30.3 \mathrm{Ab}$ & $31.1 \mathrm{Aa}$ & $20.9 \mathrm{Bb}$ & $3.4 \mathrm{Ca}$ & $1.5 \mathrm{Ab}$ & $1.9 \mathrm{Aa}$ & $1.0 \mathrm{Ab}$ \\
\hline EPAMIG-03 & $32.7 \mathrm{Ba}$ & $26.8 \mathrm{Bb}$ & $27.2 \mathrm{Ba}$ & $22.2 \mathrm{Bb}$ & $2.4 \mathrm{Da}$ & $1.3 \mathrm{Ab}$ & $1.6 \mathrm{Aa}$ & $1.1 \mathrm{Ab}$ \\
\hline Princesa & $28.9 \mathrm{Ba}$ & $29.0 \mathrm{Aa}$ & $23.5 \mathrm{Ba}$ & $24.8 \mathrm{Aa}$ & $3.4 \mathrm{Ca}$ & $1.7 \mathrm{Ab}$ & $1.8 \mathrm{Aa}$ & $1.7 \mathrm{Aa}$ \\
\hline Unknown & - & - & - & - & $3.9 \mathrm{Ba}$ & $1.6 \mathrm{Ab}$ & $1.9 \mathrm{Aa}$ & $1.3 \mathrm{Ab}$ \\
\hline Mean & & & & & & & & \\
\hline $\mathrm{CV}(\%)$ & & & & & & & & \\
\hline \multirow{3}{*}{ Accessions } & \multicolumn{4}{|c|}{---------------------S $\left(\mathrm{g} \mathrm{kg}^{-1}\right.$ )--------------------- } & \multicolumn{4}{|c|}{-----------------------Ca $\left(\mathrm{g} \mathrm{kg}^{-1}\right.$ )---------------------- } \\
\hline & \multicolumn{2}{|c|}{ Clycle I } & \multicolumn{2}{|c|}{ Clycle II } & \multicolumn{2}{|c|}{ Clycle I } & \multicolumn{2}{|c|}{ Clycle II } \\
\hline & Phase I & Phase II & Phase I & Phase II & Phase I & Phase II & Phase I & Phase II \\
\hline EPAMIG-01 & $2.2 \mathrm{Ca}$ & $2.0 \mathrm{Ba}$ & $2.7 \mathrm{Aa}$ & $2.2 \mathrm{Aa}$ & $8.1 \mathrm{Bb}$ & $33.2 \mathrm{Ba}$ & $20.2 \mathrm{Cb}$ & $40.0 \mathrm{Ca}$ \\
\hline EPAMIG-05 & $2.7 \mathrm{Ba}$ & $2.5 \mathrm{Aa}$ & $2.7 \mathrm{Aa}$ & $2.5 \mathrm{Aa}$ & $15.1 \mathrm{Ab}$ & $38.8 \mathrm{Aa}$ & $25.5 \mathrm{Bb}$ & $42.1 \mathrm{Ca}$ \\
\hline BGU-75 & $3.3 \mathrm{Aa}$ & $2.0 \mathrm{Bb}$ & $2.6 \mathrm{Aa}$ & $2.2 \mathrm{Aa}$ & $10.9 \mathrm{Bb}$ & $42.6 \mathrm{Aa}$ & $26.5 \mathrm{Bb}$ & $54.2 \mathrm{Aa}$ \\
\hline BGU-47 & $4.1 \mathrm{Aa}$ & $2.2 \mathrm{Ab}$ & $2.6 \mathrm{Aa}$ & $1.7 \mathrm{Bb}$ & $17.1 \mathrm{Ab}$ & $45.0 \mathrm{Aa}$ & $36.0 \mathrm{Ab}$ & $57.2 \mathrm{Aa}$ \\
\hline BGU-48 & $3.6 \mathrm{Aa}$ & $1.8 \mathrm{Bb}$ & $2.6 \mathrm{Aa}$ & $2.4 \mathrm{Aa}$ & $7.6 \mathrm{Bb}$ & $43.7 \mathrm{Aa}$ & $20.2 \mathrm{Cb}$ & $40.6 \mathrm{Ca}$ \\
\hline BGU-50 & $3.5 \mathrm{Aa}$ & $1.9 \mathrm{Bb}$ & $2.7 \mathrm{Aa}$ & $2.4 \mathrm{Aa}$ & $9.4 \mathrm{Bb}$ & $31.6 \mathrm{Ba}$ & $22.1 \mathrm{Cb}$ & $46.9 \mathrm{Ba}$ \\
\hline BGU-45 & $3.3 \mathrm{Aa}$ & $2.3 \mathrm{Ab}$ & $2.8 \mathrm{Aa}$ & $2.5 \mathrm{Aa}$ & $10.1 \mathrm{Bb}$ & $33.0 \mathrm{Ba}$ & $23.9 \mathrm{Bb}$ & $51.5 \mathrm{Ba}$ \\
\hline BGU-44 & $3.8 \mathrm{Aa}$ & $2.1 \mathrm{Ab}$ & $2.5 \mathrm{Aa}$ & $2.1 \mathrm{Aa}$ & $6.8 \mathrm{Bb}$ & $34.2 \mathrm{Ba}$ & $20.9 \mathrm{Cb}$ & $34.0 \mathrm{Da}$ \\
\hline EPAMIG-07 & $1.9 \mathrm{Ca}$ & $2.1 \mathrm{Aa}$ & $2.3 \mathrm{Aa}$ & $1.8 \mathrm{Ba}$ & $11.2 \mathrm{Bb}$ & $35.1 \mathrm{Ba}$ & $25.7 \mathrm{Bb}$ & 37.5 Da \\
\hline EPAMIG-09 & $3.5 \mathrm{Aa}$ & $2.1 \mathrm{Ab}$ & $2.7 \mathrm{Aa}$ & $2.0 \mathrm{Ab}$ & $8.9 \mathrm{Bb}$ & $35.3 \mathrm{Ba}$ & $20.4 \mathrm{Cb}$ & $35.2 \mathrm{Da}$ \\
\hline EPAMIG-13 & $3.6 \mathrm{Aa}$ & $1.9 \mathrm{Bb}$ & $2.3 \mathrm{Aa}$ & $1.9 \mathrm{Ba}$ & $12.0 \mathrm{Ab}$ & $26.6 \mathrm{Ba}$ & $23.5 \mathrm{Bb}$ & $43.3 \mathrm{Ca}$ \\
\hline EPAMIG-06 & $2.9 \mathrm{Ba}$ & $2.0 \mathrm{Bb}$ & $2.5 \mathrm{Aa}$ & $2.2 \mathrm{Aa}$ & $6.5 \mathrm{Bb}$ & $38.1 \mathrm{Aa}$ & $24.3 \mathrm{Bb}$ & $38.0 \mathrm{Da}$ \\
\hline EPAMIG-04 & $2.8 \mathrm{Ba}$ & $2.1 \mathrm{Ab}$ & $2.3 \mathrm{Aa}$ & $1.9 \mathrm{Ba}$ & $5.6 \mathrm{Bb}$ & $31.6 \mathrm{Ba}$ & $17.6 \mathrm{Cb}$ & 37.5 Da \\
\hline EPAMIG-03 & $2.7 \mathrm{Ba}$ & $1.8 \mathrm{Bb}$ & $2.6 \mathrm{Aa}$ & $2.2 \mathrm{Aa}$ & $13.2 \mathrm{Ab}$ & $33.7 \mathrm{Ba}$ & $20.9 \mathrm{Bb}$ & $32.9 \mathrm{Da}$ \\
\hline Princesa & $3.0 \mathrm{Ba}$ & $2.4 \mathrm{Ab}$ & $2.1 \mathrm{Aa}$ & $2.3 \mathrm{Aa}$ & $17.7 \mathrm{Ab}$ & $33.6 \mathrm{Ba}$ & $19.9 \mathrm{Cb}$ & 35.4 Da \\
\hline Unknown & $3.1 \mathrm{Ba}$ & $2.0 \mathrm{Bb}$ & $2.4 \mathrm{Aa}$ & $2.1 \mathrm{Aa}$ & $7.8 \mathrm{Bb}$ & $35.9 \mathrm{Ba}$ & $21.1 \mathrm{Bb}$ & $33.6 \mathrm{Da}$ \\
\hline Mean & & & & & & & & \\
\hline $\mathrm{CV}(\%)$ & & & & & & & & \\
\hline$\Delta$ & ----------- & K ( & $\left.\mathrm{kg}^{-1}\right)$ & ------ & - ------- & ------ Mg & $\left.\mathrm{g} \mathrm{kg}^{-1}\right)$ & ---------- \\
\hline Accessions & Phase I & Phase II & Clycle I & Clycle II & Phase I & Phase II & Clycle I & Clycle II \\
\hline EPAMIG-01 & $13.2 \mathrm{Aa}$ & $8.1 \mathrm{Ab}$ & $12.9 \mathrm{Aa}$ & $8.3 \mathrm{Ab}$ & $3.4 \mathrm{Ba}$ & $4.1 \mathrm{Ba}$ & $3.8 \mathrm{Ca}$ & $3.8 \mathrm{Ba}$ \\
\hline EPAMIG-05 & $11.1 \mathrm{Ba}$ & $8.1 \mathrm{Ab}$ & $10.2 \mathrm{Ba}$ & $9.0 \mathrm{Aa}$ & $4.0 \mathrm{Ba}$ & $3.8 \mathrm{Ba}$ & $4.2 \mathrm{Ca}$ & $3.6 \mathrm{Ba}$ \\
\hline BGU-75 & $12.4 \mathrm{Aa}$ & $5.3 \mathrm{Bb}$ & $11.2 \mathrm{Aa}$ & $6.4 \mathrm{Ab}$ & $3.3 \mathrm{Ba}$ & $4.0 \mathrm{Ba}$ & $3.6 \mathrm{Ca}$ & $3.6 \mathrm{Ba}$ \\
\hline BGU-47 & $10.8 \mathrm{Ba}$ & $5.2 \mathrm{Bb}$ & $9.5 \mathrm{Ba}$ & $6.6 \mathrm{Ab}$ & $6.1 \mathrm{Aa}$ & $5.9 \mathrm{Aa}$ & $6.8 \mathrm{Aa}$ & $5.2 \mathrm{Ab}$ \\
\hline BGU-48 & $13.7 \mathrm{Aa}$ & $5.7 \mathrm{Bb}$ & $11.6 \mathrm{Aa}$ & $7.8 \mathrm{Ab}$ & $3.2 \mathrm{Bb}$ & $4.3 \mathrm{Ba}$ & $3.7 \mathrm{Ca}$ & $3.8 \mathrm{Ba}$ \\
\hline BGU-50 & $14.8 \mathrm{Aa}$ & $5.7 \mathrm{Bb}$ & $13.3 \mathrm{Aa}$ & $7.1 \mathrm{Ab}$ & $3.4 \mathrm{Ba}$ & $3.9 \mathrm{Ba}$ & $3.2 \mathrm{Ca}$ & $4.1 \mathrm{Ba}$ \\
\hline BGU-45 & $12.7 \mathrm{Aa}$ & $5.0 \mathrm{Bb}$ & $11.3 \mathrm{Aa}$ & $6.5 \mathrm{Ab}$ & $3.3 \mathrm{Ba}$ & $4.0 \mathrm{Ba}$ & $3.4 \mathrm{Ca}$ & $3.8 \mathrm{Ba}$ \\
\hline BGU-44 & $13.7 \mathrm{Aa}$ & $6.3 \mathrm{Bb}$ & $12.0 \mathrm{Aa}$ & $7.8 \mathrm{Ab}$ & $3.3 \mathrm{Bb}$ & $4.8 \mathrm{Ba}$ & $3.5 \mathrm{Cb}$ & $4.6 \mathrm{Aa}$ \\
\hline EPAMIG-07 & $12.9 \mathrm{Aa}$ & $6.5 \mathrm{Bb}$ & $11.5 \mathrm{Aa}$ & $7.9 \mathrm{Ab}$ & $4.0 \mathrm{Bb}$ & $6.2 \mathrm{Aa}$ & 4.6 Ca & $5.5 \mathrm{Aa}$ \\
\hline EPAMIG-09 & $14.0 \mathrm{Aa}$ & $5.5 \mathrm{Bb}$ & $12.0 \mathrm{Aa}$ & $7.5 \mathrm{Ab}$ & $3.3 \mathrm{Bb}$ & 4.7 Ba & $3.5 \mathrm{Cb}$ & $4.5 \mathrm{Aa}$ \\
\hline EPAMIG-13 & $12.6 \mathrm{Aa}$ & $6.0 \mathrm{Bb}$ & $11.5 \mathrm{Aa}$ & $7.2 \mathrm{Ab}$ & $4.0 \mathrm{Ba}$ & $4.2 \mathrm{Ba}$ & $3.7 \mathrm{Ca}$ & $4.4 \mathrm{Ba}$ \\
\hline EPAMIG-06 & $13.7 \mathrm{Aa}$ & $7.1 \mathrm{Ab}$ & 12.1 Aa & $8.7 \mathrm{Ab}$ & $3.5 \mathrm{Bb}$ & 4.7 Ba & $3.6 \mathrm{Ca}$ & $4.5 \mathrm{Aa}$ \\
\hline EPAMIG-04 & $13.5 \mathrm{Aa}$ & $7.9 \mathrm{Ab}$ & $12.4 \mathrm{Aa}$ & $9.0 \mathrm{Ab}$ & $3.0 \mathrm{Bb}$ & $4.1 \mathrm{Ba}$ & $3.1 \mathrm{Ca}$ & $3.9 \mathrm{Ba}$ \\
\hline EPAMIG-03 & $10.8 \mathrm{Ba}$ & $6.4 \mathrm{Bb}$ & $9.7 \mathrm{Ba}$ & $7.4 \mathrm{Ab}$ & 4.1 Bb & $5.3 \mathrm{Ba}$ & $4.4 \mathrm{Ca}$ & $5.0 \mathrm{Aa}$ \\
\hline Princesa & $11.7 \mathrm{Ba}$ & $6.4 \mathrm{Bb}$ & $10.2 \mathrm{Ba}$ & $7.9 \mathrm{Ab}$ & $5.4 \mathrm{Aa}$ & $4.6 \mathrm{Ba}$ & $5.6 \mathrm{Ba}$ & $4.4 \mathrm{Bb}$ \\
\hline Unknown & $12.4 \mathrm{Aa}$ & $5.6 \mathrm{Bb}$ & $10.7 \mathrm{Ba}$ & $7.3 \mathrm{Ab}$ & $3.6 \mathrm{Bb}$ & $5.8 \mathrm{Aa}$ & $4.0 \mathrm{Cb}$ & $5.4 \mathrm{Aa}$ \\
\hline Mean & & & & & & & & \\
\hline $\mathrm{CV}(\%)$ & & & & & & & & \\
\hline
\end{tabular}

Nitrogen contents not presented (-) were not determined because the number of 20 sampled units was not sufficient to perform leaf analysis. Means followed by equal uppercase letters in columns, for accessions, belong to the same grouping by the Scott-Knott criterion $(\mathrm{P} \leq 0.05)$. Means followed by equal lowercase letters in rows, for phases in the same cycle, do not differ by the $\mathrm{F}$ test $(\mathrm{P} \leq 0.05)$. $\mathrm{CV}=$ coefficient of variation. 
The leaf contents of $\mathrm{Ca}$ in the cycles and phases varied between accessions, with the formation of at least two and at most four groups by the Scott-Knott criterion. The accessions had lower $\mathrm{Ca}$ contents in the leaf flushing phase in both seasons. $\mathrm{Ca}$ accumulation was observed in the senescent leaves. It is understood that part of the $\mathrm{Ca}$ from cell walls is degraded with the processes that occur in the leaf senescence, while another residual part remains in the cell wall. As Ca is little mobile in the plant, once in the tissue, it is no longer remobilized to another part of the plant (LIMA et al., 2018). Then, its biogeochemical recycling returns the nutrient from the phytomass to the environment. The accessions had an average Ca content of $27.6 \mathrm{~g}$ $\mathrm{kg}^{-1}$, for the two production cycles and the two evaluation phases, which is consistent with values close to $30 \mathrm{~g} \mathrm{~kg}^{-1}$ found in an adult native umbu tree (MEDEIROS; SANTOS; TERTULIANO, 2008).

The leaf contents of $\mathrm{K}$ and $\mathrm{Mg}$ varied in the cycles between accessions, with the formation of at least two and at most four groups, except for $\mathrm{K}$ in the 2016/2017 season, which did not form a group by the Scott-Knott criterion. The accessions had higher $\mathrm{K}$ contents in the 2015/2016 season. For the two production cycles evaluated, accessions with an average $\mathrm{K}$ content of $9.5 \mathrm{~g} \mathrm{~kg}^{-1}$ were observed, which corroborates the characteristics of the leaf contents described for the crop (MEDEIROS; SANTOS; TERTULIANO, 2008). The highest K contents observed in the $2015 / 2016$ season may be related to fertilizations performed until 2015. The absence of fertilization in the experimental area in 2016 led to lower $\mathrm{K}$ contents in the 2016/2017 season.

For most accessions, there was no significant difference between $\mathrm{Mg}$ contents in 2015/2016 and 2016/2017. The accessions had an average $\mathrm{Mg}$ content of $4.20 \mathrm{~g} \mathrm{~kg}^{-1}$ regardless of the season. In both production seasons and between phases, it was verified that the accession BGU-47 had the highest $\mathrm{Mg}$ contents. The function of $\mathrm{Mg}$ is involved in $\mathrm{pH}$ regulation and enzyme activation in the energy metabolism. The element is quite mobile in the phloem, being remobilized from the older leaves to the new ones or to the growth points (LIMA et al., 2018). However, higher $\mathrm{Mg}$ contents were observed in the senescent leaves. Also according to these authors, in most plants, the Mg contents in the young parts are higher than in the old parts, although the reverse may also occur.

It was observed that the accessions BGU-48 and EPAMIG-06 had higher percentage values of nutrient retranslocation rate for $\mathrm{N}$ compared to the other accessions in cycle I and lower percentage in Princesa umbu-caja (Table 3). The accession EPAMIG-04 had higher efficiency in the biochemical cycling of $\mathrm{N}$ in cycle II and Princesa umbu-caja had lower efficiency. Higher efficiency in the biochemical cycling of a nutrient by a given accession may mean greater nutritional saving, because the deposition of senescent leaves influences soil fertility at first and plant development in the long term (VARGAS et al., 2018).

Table 3. Retranslocation rate (RR) or magnitude of biochemical cycling of nitrogen (N), phosphorus (P), potassium K) and magnesium $(\mathrm{Mg})$ in fifteen accessions of umbu and one of umbu-caja.

\begin{tabular}{lcccccccc}
\hline \multirow{2}{*}{ Accessions } & \multicolumn{2}{c}{$\mathrm{RR}-\mathrm{N}(\%)$} & \multicolumn{2}{c}{$\mathrm{RR}-\mathrm{P}(\%)$} & \multicolumn{2}{c}{$\mathrm{RR}-\mathrm{K}(\%)$} \\
\cline { 2 - 7 } & Cycle I & Cycle II & Cycle I & Cycle II & Cycle I & Cycle II & Cycle I & Cycle II \\
\hline EPAMIG-01 & 82.13 & 54.64 & 88.61 & 55.81 & 88.71 & 53.55 & 70.98 \\
EPAMIG-05 & 65.74 & 45.83 & 77.30 & 47.51 & 81.61 & 30.26 & 65.69 & 36.71 \\
BGU-75 & 79.91 & 59.85 & 88.81 & 70.12 & 91.34 & 70.05 & 72.71 & 32.71 \\
BGU-47 & 68.20 & 51.51 & 83.88 & 56.73 & 86.18 & 56.35 & 64.69 & 35.84 \\
BGU-48 & 87.96 & 55.76 & 94.05 & 61.30 & 94.41 & 69.94 & 76.38 \\
BGU-50 & 79.99 & 64.69 & 89.86 & 68.59 & 91.47 & 70.95 & 70.56 & 40.57 \\
BGU-45 & 69.39 & 65.67 & 87.17 & 71.00 & 90.10 & 74.59 & 68.49 & 35.41 \\
BGU-44 & 86.42 & 46.97 & 92.73 & 59.02 & 92.11 & 64.61 & 76.84 & -2.74 \\
EPAMIG-07 & - & - & 84.05 & 58.12 & 87.80 & 50.16 & 53.54 & -12.05 \\
EPAMIG-09 & 79.82 & 58.05 & 91.04 & 64.12 & 92.21 & 67.70 & 71.73 & -0.34 \\
EPAMIG-13 & 64.90 & 60.27 & 78.77 & 65.72 & 83.02 & 63.33 & 65.81 & 25.56 \\
EPAMIG-06 & 87.86 & 41.22 & 93.88 & 58.43 & 93.49 & 50.69 & 78.76 \\
EPAMIG-04 & 85.17 & 68.46 & 92.18 & 75.30 & 92.02 & 61.41 & 80.31 & 23.34 \\
EPAMIG-03 & 67.90 & 48.15 & 78.78 & 56.33 & 78.65 & 57.88 & 59.94 & -2.96 \\
Princesa & 47.14 & 40.68 & 73.66 & 46.91 & 79.78 & 53.74 & 59.12 \\
Unknown & - & - & 91.09 & 57.03 & 91.92 & 63.18 & 64.96 & 0.12 \\
\hline
\end{tabular}

Nitrogen contents not presented (-) were not determined because the number of 20 sampled units was not sufficient to perform leaf analysis. 
Although $\mathrm{N}$ is considered of high mobility (SOUZA; FERNANDES, 2018), for deciduous plants such as umbu, the source-sink ratio and the remobilization have lower cycling efficiency. $\mathrm{N}$ is probably poorly remobilized from the senescent leaves to the main sink after the fruits, leaves and branches. Soon after the beginning of leaf senescence and beginning of dormancy of the branches, the xylopodium becomes the main sink in the plant, so that possibly the phytomass of fallen leaves on the soil surface contributes to $\mathrm{N}$ cycling in the soil-plant relationship.

The accessions had a lower $\mathrm{N}$ and $\mathrm{P}$ retranslocation rate percentage in cycle II compared to the percentage of the accessions in cycle I. This may be a consequence of the lower leaf contents in the leaf flushing phase of cycle II. It was verified that the accession BGU-48 had higher efficiency of biochemical cycling of $\mathrm{P}$ and the accession of umbucaja had lower efficiency in cycle I. In cycle II, the accession EPAMIG-04 obtained higher $\mathrm{P}$ retranslocation $\mathrm{P}$ rate and Princesa umbu-caja obtained lower rate. The lower retranslocation of $\mathrm{N}$ and $\mathrm{P}$ in the two seasons by the Princesa umbu-caja compared to the umbu accessions is justified by its lower degree and speed of senescence (DONATO et al., 2019a).

In plants with $\mathrm{P}$ deficiency, the supplement is mobilized from the senescent leaves to the young ones and to the roots, because this nutrient has high mobility and the distribution pattern is apparently related to the source-sink ratio, and its movement is determined by the demand of carbohydrate within the plant (MARSCHNER, 2012). In the case of umbu, which loses its leaves in the dry season, it can be considered that $\mathrm{P}$ is remobilized to the strongest sink of carbohydrates in the leaf senescence period, the xylopodia, for storage, and that will support the production of new leaves and flowering, in the subsequent season.

The accessions BGU-50 and BGU-45 had higher $\mathrm{K}$ retranslocation rate and the accession EPAMIG-05 showed lower rate. The accession BGU -50 also had a higher percentage of $\mathrm{Mg}$ retranslocation, while EPAMIG-07 showed a lower percentage. The genetic characteristic of the accession is one of the main factors for higher efficiency of biochemical recycling, enabling these accessions of higher percentage in the nutrient retranslocation rate to be possibly more efficient and less demanding in terms of nutritional supply and an option for cultivation under poorer soil conditions or aiming at reduction of costs in fertilization.

The accessions had higher leaf $\mathrm{K}$ contents in the leaf flushing phase. This can be justified by the need for supply from the phloem to the young leaves, meristematic tissues and fresh fruits
(MARSCHNER, 2012). On the other hand, it should also be considered, in senescence, that there is a reduction in the $\mathrm{K}$ content in the leaves, when there is no or reduced requirement for young leaves, fruits and/or growth of branches, and $\mathrm{K}$ is easily translocated between cells and tissues (MARSCHNER, 2012). Possibly, K should be transported to the xylopodia, understood as a sink, due to the adaptive need of umbu and umbu-caja to store nutrients and water in the tuberous roots, for the supply that will be used in flowering, in the next season. In addition to the biogeochemical cycling of $\mathrm{K}$ with the allocation from leaf tissues to xylopodium, the influence of this cycling was also verified, with loss of the nutrient from the leaves by leaching from the end of 2016 to January 2017, by the precipitations shown in Figure 1.

$\mathrm{K}$ is a nutrient of high mobility, with an important function in osmotic control, in favoring of the transport and storage of carbohydrates, and in the participation in starch synthesis in the leaf (MEURER; TIECHER; MATTIELLO, 2018). In addition, when the soil provides adequate amount of $\mathrm{K}$ for the plant, it affects the starch contents in fruits and xylopodia, color and aroma of the fruit, vitamin $\mathrm{C}$ content, and contents of soluble solids can be increased.

The higher translocation rate observed in the year of greater stress by drought and heat, 2015 (Figure 1), accelerates senescence, contributes to increasing the nutritional and photosynthetic efficiency of the plant (TAIZ et al., 2017), and ensures the accumulation of reserves of nutrients and photoassimilates for the subsequent season. Nutrients such as $\mathrm{K}$ and $\mathrm{Mg}$ play an essential role in the loading and transport of sugars via phloem. The speed of transport of carbon from leaves to other organs depends on the adequate supply of these nutrients (CAKMAK; KIRKBY, 2008; CAKMAK, 2013). This capacity for storing carbohydrates in reserve organs, such as the tubers, and subsequent translocation contribute significantly to the stability of high yield under stress conditions.

Leaf contents of B formed from two to three groups for accessions in the evaluated phases and cycles (Table 4). Only the leaf flushing of the 2015/2016 season did not form distinct groups. In general, there was accumulation of B content in the senescent leaves of the $2015 / 2016$ season, while in the 2016/2017 season, the young leaves had high values of $B$, which stabilized in the senescence, except for the accessions EPAMIG-05 and BGU-44, which increased $\mathrm{B}$ contents in the senescence. The accessions had, in both production cycles and evaluation phases, an average B content of $86.22 \mathrm{mg}$ $\mathrm{kg}^{-1}$. 
Table 4. Leaf contents of boron (B), copper $(\mathrm{Cu})$, zinc $(\mathrm{Zn})$, iron $(\mathrm{Fe})$ and manganese $(\mathrm{Mn})$ of fifteen accessions of umbu and one of umbu-caja in two sampling phases, leaf flushing (I) and leaf senescence (II) in two production cycles, 2015-2016 (I) and 2016-2017 (II).

\begin{tabular}{|c|c|c|c|c|c|c|c|c|}
\hline \multirow{3}{*}{ Accessions } & \multicolumn{4}{|c|}{$\mathrm{B}\left(\mathrm{mg} \mathrm{kg}^{-1}\right)$} & \multicolumn{4}{|c|}{$\mathrm{Cu}\left(\mathrm{mg} \mathrm{kg}^{-1}\right)$} \\
\hline & \multicolumn{2}{|c|}{ Cycle I } & \multicolumn{2}{|c|}{ Cycle II } & \multicolumn{2}{|c|}{ Cycle I } & \multicolumn{2}{|c|}{ Cycle II } \\
\hline & Phase I & Phase II & Phase I & Phase II & Phase I & Phase II & Phase I & Phase II \\
\hline EPAMIG-01 & - & - & - & - & $5.4 \mathrm{Aa}$ & $2.6 \mathrm{Ab}$ & $4.2 \mathrm{Aa}$ & $4.7 \mathrm{Aa}$ \\
\hline EPAMIG-05 & $41.4 \mathrm{Ab}$ & $70.7 \mathrm{Ca}$ & $65.9 \mathrm{Bb}$ & $85.9 \mathrm{Ba}$ & $4.6 \mathrm{Aa}$ & $1.6 \mathrm{Ab}$ & $2.7 \mathrm{Ba}$ & $2.1 \mathrm{Ba}$ \\
\hline BGU-75 & $50.0 \mathrm{Ab}$ & $117.5 \mathrm{Aa}$ & $97.5 \mathrm{Aa}$ & $97.4 \mathrm{Ba}$ & $5.7 \mathrm{Aa}$ & $2.2 \mathrm{Ab}$ & $3.1 \mathrm{Ba}$ & $4.0 \mathrm{Aa}$ \\
\hline BGU-47 & - & - & - & - & $4.9 \mathrm{Aa}$ & $3.1 \mathrm{Aa}$ & $3.2 \mathrm{Aa}$ & $1.3 \mathrm{Bb}$ \\
\hline BGU48 & - & - & - & - & $5.6 \mathrm{Aa}$ & $1.8 \mathrm{Ab}$ & $2.1 \mathrm{Ba}$ & $3.0 \mathrm{Ba}$ \\
\hline BGU-50 & - & - & - & - & $5.7 \mathrm{Aa}$ & $4.2 \mathrm{Aa}$ & $5.0 \mathrm{Aa}$ & $2.7 \mathrm{Bb}$ \\
\hline BGU-45 & $51.7 \mathrm{Ab}$ & $108.2 \mathrm{Ba}$ & $107.5 \mathrm{Aa}$ & $113.9 \mathrm{Aa}$ & $4.1 \mathrm{Ba}$ & $1.5 \mathrm{Ab}$ & $3.8 \mathrm{Aa}$ & $1.8 \mathrm{Bb}$ \\
\hline BGU-44 & $43.6 \mathrm{Ab}$ & $107.4 \mathrm{Ba}$ & $71.4 \mathrm{Bb}$ & $107.7 \mathrm{Aa}$ & $5.7 \mathrm{Aa}$ & $3.4 \mathrm{Ab}$ & $3.7 \mathrm{Aa}$ & $1.1 \mathrm{Bb}$ \\
\hline EPAMIG-07 & - & - & - & - & $5.2 \mathrm{Aa}$ & $2.8 \mathrm{Ab}$ & $3.1 \mathrm{Ba}$ & $0.8 \mathrm{Bb}$ \\
\hline EPAMIG-09 & - & - & - & - & $7.3 \mathrm{Aa}$ & $2.6 \mathrm{Ab}$ & $4.4 \mathrm{Aa}$ & $1.3 \mathrm{Bb}$ \\
\hline EPAMIG-13 & $61.5 \mathrm{Ab}$ & 127.1 Aa & $117.5 \mathrm{Aa}$ & $117.8 \mathrm{Aa}$ & $5.0 \mathrm{Aa}$ & $2.7 \mathrm{Ab}$ & $3.1 \mathrm{Aa}$ & $0.6 \mathrm{Bb}$ \\
\hline EPAMIG-06 & - & - & - & - & $4.2 \mathrm{Ba}$ & $2.9 \mathrm{Aa}$ & $1.4 \mathrm{Bb}$ & $4.6 \mathrm{Aa}$ \\
\hline EPAMIG-04 & $49.0 \mathrm{Ab}$ & $96.1 \mathrm{Ba}$ & $93.5 \mathrm{Aa}$ & $99.8 \mathrm{Ba}$ & $5.0 \mathrm{Aa}$ & $0.9 \mathrm{Ab}$ & $2.0 \mathrm{Ab}$ & $5.4 \mathrm{Aa}$ \\
\hline EPAMIG-03 & $53.9 \mathrm{Ab}$ & $78.5 \mathrm{Ca}$ & $97.5 \mathrm{Aa}$ & $83.0 \mathrm{Ba}$ & $4.4 \mathrm{Ba}$ & $1.9 \mathrm{Ab}$ & $2.6 \mathrm{Bb}$ & $5.8 \mathrm{Aa}$ \\
\hline Princesa & - & - & - & - & $4.9 \mathrm{Aa}$ & $3.7 \mathrm{Aa}$ & $2.8 \mathrm{Bb}$ & $5.3 \mathrm{Aa}$ \\
\hline Unknown & - & - & - & - & $3.9 \mathrm{Ba}$ & $2.2 \mathrm{Ab}$ & $3.8 \mathrm{Aa}$ & $5.6 \mathrm{Aa}$ \\
\hline Mean & \multicolumn{4}{|c|}{86.22} & \multicolumn{4}{|c|}{3.52} \\
\hline $\mathrm{CV}(\%)$ & \multicolumn{4}{|c|}{13.11} & \multicolumn{4}{|c|}{37.50} \\
\hline \multirow{3}{*}{ Accessions } & \multicolumn{8}{|c|}{$\mathrm{Zn}\left(\mathrm{mg} \mathrm{kg}^{-1}\right)$} \\
\hline & \multicolumn{4}{|c|}{ Cycle I } & & Cycle & II & \\
\hline & & hase I & & Phase II & & & Pha & \\
\hline EPAMIG-01 & & $4.17 \mathrm{Ba}$ & & $14.98 \mathrm{Bb}$ & & & 10.4 & $\mathrm{Ba}$ \\
\hline EPAMIG-05 & & $7.89 \mathrm{Ba}$ & & $17.11 \mathrm{Ba}$ & & $\mathrm{Aa}$ & 10.8 & $\mathrm{Ba}$ \\
\hline BGU-75 & & $1.16 \mathrm{Ba}$ & & $21.67 \mathrm{Aa}$ & & $\mathrm{Aa}$ & 6.49 & \\
\hline BGU-47 & & $3.51 \mathrm{Ba}$ & & $12.41 \mathrm{Bb}$ & & $\mathrm{Aa}$ & 10.5 & $\mathrm{Ba}$ \\
\hline BGU48 & & $3.12 \mathrm{Ba}$ & & $18.72 \mathrm{Aa}$ & & $\mathrm{Ab}$ & 16.7 & $\mathrm{Aa}$ \\
\hline BGU-50 & & $1.45 \mathrm{Ba}$ & & $19.83 \mathrm{Aa}$ & & $\mathrm{Aa}$ & 11.5 & $\mathrm{Ba}$ \\
\hline BGU-45 & & $2.73 \mathrm{Ba}$ & & $18.83 \mathrm{Aa}$ & & $\mathrm{Aa}$ & 11.0 & $\mathrm{Ba}$ \\
\hline BGU-44 & & $.38 \mathrm{Ba}$ & & $24.25 \mathrm{Aa}$ & & $\mathrm{Aa}$ & 13.0 & $\mathrm{Ba}$ \\
\hline EPAMIG-07 & & $1.27 \mathrm{Ba}$ & & $14.55 \mathrm{Bb}$ & & $\mathrm{Aa}$ & 13.0 & $\mathrm{Ba}$ \\
\hline EPAMIG-09 & & $3.12 \mathrm{Ba}$ & & $14.54 \mathrm{Bb}$ & & $\mathrm{Aa}$ & 13.0 & $\mathrm{Ba}$ \\
\hline EPAMIG-13 & & $3.21 \mathrm{Ba}$ & & $16.15 \mathrm{Bb}$ & & $\mathrm{Aa}$ & 9.47 & \\
\hline EPAMIG-06 & & $.46 \mathrm{Aa}$ & & $10.70 \mathrm{Bb}$ & & $\mathrm{Ba}$ & 11.8 & $\mathrm{Ba}$ \\
\hline EPAMIG-04 & & $1.91 \mathrm{Aa}$ & & $18.83 \mathrm{Ab}$ & & $\mathrm{Aa}$ & 10.1 & $\mathrm{Ba}$ \\
\hline EPAMIG-03 & & $1.27 \mathrm{Ba}$ & & $14.55 \mathrm{Bb}$ & & $\mathrm{Aa}$ & 12.3 & $\mathrm{Ba}$ \\
\hline Princesa & & $3.42 \mathrm{Ba}$ & & $15.4 \mathrm{Ba}$ & & $\mathrm{Ab}$ & 20.5 & $\mathrm{Aa}$ \\
\hline Unknown & & $8.81 \mathrm{Ba}$ & & $14.55 \mathrm{Ba}$ & & $\mathrm{Aa}$ & 15.2 & $\mathrm{Aa}$ \\
\hline Mean & & & & & & & & \\
\hline CV (\%) & & & & & & & & \\
\hline Accessions & ------ F & $\mathrm{e}\left(\mathrm{mg} \mathrm{kg}^{-1}\right)$ & --- & & --------- Mr & $\left.\mathrm{g} \mathrm{kg}^{-1}\right)$----- & ---------- & \\
\hline Accessions & Phase I & & ise II & Cycle I & Cycle II & Phase I & & ase II \\
\hline EPAMIG-01 & $88.5 \mathrm{Ba}$ & & $0 \mathrm{Ba}$ & $31.75 \mathrm{Ca}$ & $45.47 \mathrm{Da}$ & $25.1 \mathrm{Cb}$ & & $1 \mathrm{Da}$ \\
\hline EPAMIG-05 & $128.7 \mathrm{Aa}$ & & $.4 \mathrm{Ba}$ & $54.31 \mathrm{Ca}$ & $54.13 \mathrm{Ca}$ & $40.1 \mathrm{Cb}$ & & $2 \mathrm{Ca}$ \\
\hline BGU-75 & $95.9 \mathrm{Aa}$ & & $.3 \mathrm{Ba}$ & $36.17 \mathrm{Ca}$ & $39.18 \mathrm{Da}$ & $32.9 \mathrm{Cb}$ & & $6 \mathrm{Ca}$ \\
\hline BGU-47 & $102.4 \mathrm{Aa}$ & & $.9 \mathrm{Ba}$ & $48.20 \mathrm{Ca}$ & $61.29 \mathrm{Ca}$ & $44.8 \mathrm{Cb}$ & & $1 \mathrm{Ca}$ \\
\hline BGU-48 & $73.6 \mathrm{Bb}$ & & $.3 \mathrm{Aa}$ & $65.63 \mathrm{Ba}$ & $64.28 \mathrm{Ca}$ & $36.9 \mathrm{Cb}$ & & $5 \mathrm{Ca}$ \\
\hline BGU-50 & 101.0Aa & & $.7 \mathrm{Aa}$ & $54.64 \mathrm{Ca}$ & $65.89 \mathrm{Ca}$ & $36.8 \mathrm{Cb}$ & & $2 \mathrm{Da}$ \\
\hline BGU-45 & $89.2 \mathrm{Ba}$ & & $6 \mathrm{Ba}$ & $41.56 \mathrm{Ca}$ & $57.48 \mathrm{Ca}$ & $31.0 \mathrm{Ca}$ & & $4 \mathrm{Da}$ \\
\hline BGU-44 & $96.4 \mathrm{Aa}$ & & $.9 \mathrm{Aa}$ & $34.76 \mathrm{Ca}$ & $46.73 \mathrm{Da}$ & $54.7 \mathrm{Bb}$ & & $2 \mathrm{Ba}$ \\
\hline EPAMIG-07 & 127.9Aa & & $.8 \mathrm{Aa}$ & $81.99 \mathrm{Ba}$ & $89.00 \mathrm{Ba}$ & $80.2 \mathrm{Ab}$ & & $.9 \mathrm{Aa}$ \\
\hline EPAMIG-09 & $83.1 \mathrm{Bb}$ & & $9 \mathrm{Aa}$ & $67.89 \mathrm{Bb}$ & $97.96 \mathrm{Ba}$ & $36.0 \mathrm{Cb}$ & & $9 \mathrm{Ca}$ \\
\hline EPAMIG-13 & 103.7Aa & & $.2 \mathrm{Aa}$ & $104.73 \mathrm{Ab}$ & $137.42 \mathrm{Aa}$ & $23.3 \mathrm{Cb}$ & & $5 \mathrm{Ca}$ \\
\hline EPAMIG-06 & $91.9 \mathrm{Ba}$ & & $1 \mathrm{Ba}$ & $54.65 \mathrm{Ca}$ & $70.31 \mathrm{Ca}$ & $27.2 \mathrm{Ca}$ & & $8 \mathrm{Da}$ \\
\hline EPAMIG-04 & $97.5 \mathrm{Aa}$ & & $.8 \mathrm{Aa}$ & $78.01 \mathrm{Ba}$ & $34.86 \mathrm{Db}$ & $33.3 \mathrm{Cb}$ & & $6 \mathrm{Ca}$ \\
\hline EPAMIG-03 & $111.4 \mathrm{Aa}$ & & $.3 \mathrm{Aa}$ & $39.44 \mathrm{Ca}$ & $36.63 \mathrm{Da}$ & $40.1 \mathrm{Cb}$ & & $6 \mathrm{Ca}$ \\
\hline Princesa & $76.8 \mathrm{Ba}$ & & $6 \mathrm{Ba}$ & $58.96 \mathrm{Ca}$ & $57.96 \mathrm{Ca}$ & $27.2 \mathrm{Ca}$ & & $1 \mathrm{Da}$ \\
\hline Unknown & $91.1 \mathrm{Ba}$ & 11 & $.4 \mathrm{Aa}$ & $52.89 \mathrm{Ca}$ & $63.91 \mathrm{Ca}$ & $49.8 \mathrm{Bb}$ & & $.0 \mathrm{Ba}$ \\
\hline Mean & & 103.6 & & & & .2 & & \\
\hline CV (\%) & & 26.5 & & & & 3.4 & & \\
\hline
\end{tabular}

Boron contents not presented (-) were not determined because the number of 20 sampled units was not sufficient to perform leaf analysis. Means followed by equal uppercase letters in columns, for accessions, belong to the same grouping by the Scott-Knott criterion $(\mathrm{P} \leq 0.05)$. Means followed by equal lowercase letters in the rows, for phases in the same cycle, do not differ by the $\mathrm{F}$ test $(\mathrm{P} \leq 0.05), \mathrm{CV}=$ coefficient of variation. 
$\mathrm{Cu}$ contents formed two groups between accessions, except for the leaf senescence phase of the $2015 / 2016$ season, with one group. In turn, the leaf contents of $\mathrm{Zn}$ formed two groups between the accessions in the cycles and phases evaluated.

The accessions showed variations in $\mathrm{Cu}$ and $\mathrm{Zn}$ contents between phases and cycles evaluated. The $\mathrm{Cu}$ content decreased in the senescence of the 2015/2016 season, except for the accessions EPAMIG-06, BGU-47, BGU-50 and Princesa umbucaja, which did not differentiate between phases. The accessions showed average $\mathrm{Cu}$ and $\mathrm{Zn}$ contents of $3.52 \mathrm{mg} \mathrm{kg} \mathrm{kg}^{-1}$ and $16 \mathrm{mg} \mathrm{kg} \mathrm{kg}^{-1}$, respectively, considering two production cycles and two evaluation phases.

$\mathrm{Cu}$ is a constituent of oxidation-reduction enzymes and is part of other enzymes, such as polyphenol oxidase, which catalyzes phenolic compounds to ketones while forming cuticle lignin. This element is not considered readily mobile in the plant, but there are reports of $\mathrm{Cu}$ translocation from old leaves to young leaves. Conversely, $\mathrm{Zn}$, which is considered highly or intermediately mobile in the plant, is present at higher concentrations in the root, plays the role of enzymatic cofactor, and regulates and stabilizes the protein structure (DECHEN et al., 2018).

There was a significant difference between Mn contents in 2015/2016 and 2016/2017. The accession EPAMIG-13 showed higher Mn contents in both cycles compared to the other accessions, with an average content of $60.20 \mathrm{mg} \mathrm{kg}^{-1}$ regardless of the season.

The variation in $\mathrm{Mn}$ contents between accessions was higher, forming three and four groups, in the phases of leaf flushing and leaf senescence, respectively. The accessions BGU-47, EPAMIG-07, Princesa umbu-caja and umbu of unknown origin stood out from the others in the evaluated phases. Half of the accessions had higher Mn contents in the leaf senescence phase, which was observed in BGU-48, BGU-44, EPAMIG-07, EPAMIG-09, EPAMIG-06, EPAMIG-04, EPAMIG03 and umbu of unknown origin. For $\mathrm{Fe}$, there was no difference between leaf flushing and leaf senescence. The Mn considered immobile, in some cases of low mobility, is fundamental for chlorophyll synthesis and plays the role of activation of enzymes (DECHEN et al., 2018).

The accessions showed, for the two collection phases, an average Fe content of $103.61 \mathrm{mg} \mathrm{kg}^{-1}$, which is consistent with the values described for umbu (MEDEIROS; SANTOS; TERTULIANO, $2008)$. Fe plays a role in the activation of enzymes, catalyzes chlorophyll formation, and is considered immobile in plant tissues (DECHEN et al., 2018). This explains its stability in leaf flushing and leaf senescence.

The leaf contents of $\mathrm{K}, \mathrm{Mg}, \mathrm{Fe}, \mathrm{Mn}$ and $\mathrm{Na}$ varied between phases in the two cycles evaluated, forming two groups, except for the leaf contents of $\mathrm{Mg}$ and $\mathrm{Fe}$, in cycle $\mathrm{I}$, and $\mathrm{Na}$, in the 2016/2017 season (Table 5). The highest leaf content of $\mathrm{K}$ was observed in the leaf flushing phase of the 2015/2016 season, regardless of accession. In the senescent leaves of the plants, the content of this nutrient was higher in 2016/2017. In turn, the average Fe content was lower in the leaf flushing phase of the 2016/2017 season. There was a lower Mn content in the leaf flushing phase in 2015/2016. The highest leaf content of $\mathrm{Na}$ was observed in the leaf flushing phase in $2015 / 2016$, equal to $130.900 \mathrm{mg} \mathrm{kg}^{-1}$.

Table 5. Average leaf contents of potassium $(\mathrm{K})$, magnesium $(\mathrm{Mg})$, iron $(\mathrm{Fe})$, manganese $(\mathrm{Mn})$ and sodium $(\mathrm{Na})$ in phases of leaf flushing (I) and leaf senescence (II) in two production cycles, 2015-2016 (I) and 2016-2017 (II).

\begin{tabular}{|c|c|c|c|c|c|c|c|c|c|c|}
\hline \multirow{2}{*}{ Phases } & \multicolumn{2}{|c|}{$\mathrm{K}\left(\mathrm{g} \mathrm{kg}^{-1}\right)$} & \multicolumn{2}{|c|}{$\mathrm{Mg}\left(\mathrm{g} \mathrm{kg}^{-1}\right)$} & \multicolumn{2}{|c|}{$\mathrm{Fe}\left(\mathrm{mg} \mathrm{kg}^{-1}\right)$} & \multicolumn{2}{|c|}{$\mathrm{Mn}\left(\mathrm{mg} \mathrm{kg}^{-1}\right)$} & \multicolumn{2}{|c|}{$\mathrm{Na}\left(\mathrm{mg} \mathrm{kg}^{-1}\right)$} \\
\hline & Cycle I & Cycle II & Cycle I & Cycle II & Cycle I & Cycle II & Cycle I & Cycle II & Cycle I & Cycle II \\
\hline I & 16.5 Aa & $9.0 \mathrm{Ab}$ & $3.9 \mathrm{Aa}$ & $3.7 \mathrm{Ba}$ & $112.4 \mathrm{Aa}$ & $82.5 \mathrm{Bb}$ & $28.9 \mathrm{Bb}$ & $48.5 \mathrm{Ba}$ & $130.9 \mathrm{Aa}$ & $56.1 \mathrm{Ab}$ \\
\hline II & $6.3 \mathrm{Ba}$ & $6.3 \mathrm{Ba}$ & $4.2 \mathrm{Ab}$ & $5.1 \mathrm{Aa}$ & $108.1 \mathrm{Aa}$ & 111. $4 \mathrm{Aa}$ & $84.2 \mathrm{Aa}$ & $79.2 \mathrm{Aa}$ & $48.8 \mathrm{Ba}$ & $92.6 \mathrm{Aa}$ \\
\hline Mean & \multicolumn{2}{|c|}{9.5} & \multicolumn{2}{|c|}{4.2} & \multicolumn{2}{|c|}{103.6} & \multicolumn{2}{|c|}{60.2} & \multicolumn{2}{|c|}{82.1} \\
\hline CV (\%) & \multicolumn{2}{|c|}{16.7} & \multicolumn{2}{|c|}{21.8} & \multicolumn{2}{|c|}{26.5} & \multicolumn{2}{|c|}{33.4} & \multicolumn{2}{|c|}{143.0} \\
\hline
\end{tabular}

*Means followed by equal uppercase letters in columns, for phases, and lowercase letters in rows, for cycles, do not differ by the $\mathrm{F}$ test $(\mathrm{P} \leq 0.05)$. $\mathrm{CV}=$ coefficient of variation.

According to Neves, Sá and Carvalho (2004), who evaluated the omission of micronutrients in umbu seedlings, there was a higher requirement of B, $\mathrm{Fe}$ and $\mathrm{Zn}$ in the initial growth phase compared to $\mathrm{Mn}$ and $\mathrm{Cu}$. On the other hand, Gonçalves, Neves and Carvalho (2006), evaluating the omission of macronutrients, observed greater requirement of $\mathrm{N}$, $\mathrm{K}, \mathrm{Ca}$ and $\mathrm{Mg}$ in the initial growth phase of umbu seedlings.

Also to understand the variation that occurs in leaf contents of nutrients between accessions, Faquin (2005) stated that the process of nutrient absorption is regulated by genetic control. Thus, the selectivity and speed of absorption depend on the absorption characteristics of the genotype. Thus, in addition to the supply of nutrients in the soil, the genetic 
characteristics of each accession can interfere in the leaf contents of nutrients. The leaf contents of nutrients in plants influence the availability of elements for their physiological processes and, consequently, the development of the accession.

\section{CONCLUSIONS}

The accession BGU-48 has higher efficiency of nitrogen and phosphorus retranslocation in the leaves, while BGU-50 showed recycling efficiency for potassium and magnesium.

The order of the retranslocation rates is $\mathrm{K}>\mathrm{P}>\mathrm{N}>\mathrm{Mg}$, being higher in the $2015 / 2016$ season.

The accessions show the following decreasing order of accumulation of macronutrients: $\mathrm{N}>\mathrm{Ca}>\mathrm{K}>\mathrm{Mg}>\mathrm{S}>\mathrm{P}$; and micronutrients: $\mathrm{Fe}>\mathrm{B}>\mathrm{Na}>\mathrm{Mn}>\mathrm{Zn}>\mathrm{Cu}$.

\section{REFERENCES}

ALBUQUERQUE, A. S. et al. Efficiency of biological utilization of micronutrients by forests species in hypoxerophytic Caatinga. Floresta e Ambiente, 25: 01-10, 2018.

ANTUNES, W. C. et al. Spondias tuberosa trees grown in tropical, wet environments are more susceptible to drought than those grown in arid environments. Revista Colombiana de Ciencias Hortícolas, 10: 9-27, 2016.

BASTOS, J. S.; MARTINEZ, E. A.; SOUZA, S. M. A. Características físico-químicas da polpa de umbu (Spondias tuberosa Arruda Camara) comercial: Efeito da concentração. Journal of Bioenergy and Food Science, 3: 11-16, 2016.

CAKMAK, I. Magnesium in crop production, food quality and human health. Plant and soil, 368: 1-4, 2013.

CAKMAK, I.; KIRKBY, E. A. Role of magnesium in carbon partitioning and alleviating photooxidative damage. Physiologia Plantarum, 133: 692-704, 2008.

CAMPOS, C. O. et al. Caracterização de umbu (Spondia tuberosa) durante seu desenvolvimento.

Revista Iberoamericana de Tecnología Postcosecha, 19: 159-166, 2018.

CHUYONG, G. B.; NEWBERY, D. M.; SONGWE, $\mathrm{N}$ C. Litter nutrient nd retranslocation in a central African rain forest dominated by ectomycorrhizal trees. New Phytologist, 148: 493-510, 2000.
DECHEN, A. R. et al. Micronutrientes. In: FERNANDES, M. S.; SOUZA, S. R. de.; SANTOS, L. A. (Eds). Nutrição mineral de plantas. Viçosa, MG: Sociedade Brasileira de Ciências do Solo, 2018. v. 2, cap. 14, p. 491-562.

DONATO, S. L. R. et al. Aspectos ecofisiológicos, morfológicos, fenológicos e de produção do umbuzeiro e da umbucajazeira. Informe Agropecuário, 40: 7-17, 2019a.

DONATO, S. L. R. et al. Práticas de cultivo do umbuzeiro. Informe Agropecuário, 40: 65-79, 2019b.

FAQUIN, V. Nutrição Mineral de Plantas. Lavras: UFLA/FAEPE. Pós-Graduação "Lato Sensu" (Especialização) a Distância: Solos e Meio Ambiente, 2005.

FREITAS, W. E. S. et al. Different 'umbu-cajá' clones fruit quality. Científica, 43: 236-240, 2015.

GONÇALVES, F. C.; NEVES, O. S. C.; CARVALHO, J. G. Deficiência nutricional em mudas de umbuzeiro decorrente da omissão de macronutrientes. Pesquisa Agropecuária Brasileira, 41: 1053-1057, 2006.

ISAH, O. A.; OMOROGIUWA, L. E.; OKUNADE, S. A. B. Chemical evaluation of some browse plants eaten by local breeds of goats in Edo state, Nigeria. The Pacific Journal of Science and Technology, 14: 406-412, 2013.

LIMA, E. et al. Cálcio e Magnésio. In: FERNANDES, M. S.; SOUZA, S. R.; SANTOS, L. A. (Eds). Nutrição mineral de plantas. Viçosa, MG: Sociedade Brasileira de Ciências do Solo, 2018. v. 2 , cap. 14 , p. $465-490$.

LIMA FILHO, J. M. P.; AIDAR, S. T. Ecofisiologia. In: DRUMOND, M. A; AIDAR, S. T; NASCIMENTO, C. E. S; OLIVEIRA, V. R. (Eds.). Umbuzeiro: avanços e perspectivas. Petrolina, PE: Embrapa Semiárido, 2016. v. 1, cap. 4, p. 117-146.

LIMA FILHO, J. M. P.; SANTOS, C. A. F. Avaliações fenotípicas e fisiológicas de espécies de spondias tendo como porta enxerto o umbuzeiro (Spondias tuberosa Cam.). Revista Caatinga, 22: 59 $-63,2009$.

LINS NETO, E. M. F.; PERONI, N.; ALBUQUERQUE, U. P. Traditional knowledge and management of umbu (Spondias tuberosa, Anacardiaceae): an endemic species from the semiarid region of northeastern Brazil. Economic Botany, 64: 11-211, 2010. 
MALAVOLTA, E.; VITTI, G. C.; OLIVEIRA, S. A. Avaliação do estado Nutricional das plantas: princípios e aplicações. 1. ed. Piracicaba, SP: Associação Brasileira para Pesquisa da Potassa e do Fosfato, 1989. $201 \mathrm{p}$

MARSCHNER, P. Marschner's mineral nutrition of higher plants. 3.rd ed. Amsterdam: Elsevier, 2012. $651 \mathrm{p}$.

MEDEIROS, M. L. D.; SANTOS, R. V.; TERTULIANO, S. S. X. Avaliação do estado nutricional de dez espécies arbóreas ocorrentes no semi-árido paraibano. Revista Caatinga, 21: 31-39, 2008.

MENDES, N. V. B. et al. Agrochemicals and stem cutting types for plantlet production of Spondias sp. Revista Caatinga, 32: 1104-1110, 2019.

MERTENS, J. et al. Spondias tuberosa Arruda (Anacardiaceae), a threatened tree of the Brazilian Caatinga?. Brazilian Journal of Biology, 77: 542$552,2017$.

MEURER, E. J.; TIECHER, T.; MATTIELLO, L. Potássio. In: FERNANDES, M. S.; SOUZA, S. R.; SANTOS, L. A. (Eds). Nutrição mineral de plantas. Viçosa, MG: Sociedade Brasileira de Ciências do Solo, 2018. v. 2, cap. 12, p. 429-464.

MITCHELL, J. D.; DALY, D. C. A revision of Spondias L. (Anacardiaceae) in the Neotropics. PhytoKeys, 55: 1-92, 2015.

NEVES, O. S. C.; SÁ, J. R.; CARVALHO, J. G. Crescimento e sintomas visuais de deficiências de micronutrientes em umbuzeiros. Revista Brasileira de Fruticultura, 26: 306-309, 2004.

OLIVEIRA, V. R. et al. Recursos genéticos. In: DRUMOND, M. A; AIDAR, S. T; NASCIMENTO, C. E. S; OLIVEIRA, V. R. (Eds.). Umbuzeiro: avanços e perspectivas. Petrolina, PE: Embrapa Semiárido, 2016. v. 1, cap. 3, p. 81-116.

SANTOS, C. A. F.; NASCIMENTO, C. E. S.; OLIVEIRA, M. C. Recursos genéticos do umbuzeiro: preservação, utilização e abordagem metodológica. In: Queiroz, M. A. de; GOEDERT, C. O; RAMOS, S. R. R. (Eds.). Recursos genéticos e melhoramento de plantas para o Nordeste brasileiro. Petrolina, PE: Embrapa Semiárido/ Brasilia, DF: Embrapa Recursos Genéticos e Biotecnologia, 1999. v. 1, cap. 4, p. 808-819.
SILVA, E. B. Informações sobre a cultura do umbuzeiro. 1. ed. Nova Porteirinha, MG: EPAMIGCTNM, 2000. 6 p. (Circular Técnica, 8).

SILVA, E. B.; GONÇALVES, N. P.; PINHO, P. J. Limitações nutricionais para crescimento de mudas de umbuzeiro em Latossolo Vermelho distrófico no Norte de Minas. Acta Scientiarum. Agronomy, 27: 55-59, 2005.

SOUZA, S. R.; FERNANDES, M. S. Nitrogênio. In: FERNANDES, M. S.; SOUZA, S. R.; SANTOS, L. A.(Eds). Nutrição mineral de plantas. Viçosa, MG: Sociedade Brasileira de Ciências do Solo, 2018. v. 2 , cap. 9, p. 309-376.

TAIZ, L. et al. Fisiologia e desenvolvimento vegetal. 6. ed. Porto Alegre, RS: Artmed, 2017. 888 p.

VARGAS, G. R. et al. Ciclagem de biomassa e nutrientes em plantios florestais. Pesquisa Aplicada \& Agrotecnologia, 11: 111-123, 2018.

VITTI, G. C. et al. Enxofre. In: FERNANDES, M. S.; SOUZA, S. R.; SANTOS, L. A. (Eds). Nutrição mineral de plantas. Sociedade Brasileira de Ciências do Solo, 2018. Viçosa, MG: Sociedade Brasileira de Ciências do Solo, 2018. v. 2, cap. 10, p. $377-400$.

SATURNINO, H. M.; GONÇALVES, N. P.; 